\title{
B Cells Accumulate in the Cerebrospinal Fluid in Inflammatory Neurological Diseases
}

\section{Viktoria Gredler and Markus Reindl*}

Clinical Department of Neurology, Innsbruck Medical University, Austria

\begin{abstract}
The contribution of B lymphocytes and their products to the pathogenesis of inflammatory diseases of the central nervous system is still not fully understood. Beside their role as precursors of antibody-secreting cells, B cells participate in the regulation of $\mathrm{T}$ cell activation through their antigen-presenting capacity, the production of cytokines and chemokines and the formation of ectopic germinal centers in intermeningeal spaces. This article reviews the current knowledge on B cells within the cerebrospinal fluid in inflammatory diseases affecting the central nervous system. Here, we will focus on two prototypical inflammatory diseases of the central nervous system: multiple sclerosis, an autoimmune-mediated inflammatory disease, and infection-triggered inflammation in Lyme neuroborreliosis.
\end{abstract}

Keywords: Cerebrospinal fluid; B cells; Inflammation; Multiple sclerosis; Neuroborreliosis

Abbreviations: CD: Cluster of Differentiation; CIS: Clinically
Isolated Syndrome; CNS: Central Nervous System; CPMS: Chronic
Progressive Multiple Sclerosis; CSF: Cerebrospinal Fluid; HIV: Human
Immunodeficiency Virus; Ig: Immunoglobulin; MBP: Myelin Basic
Protein; MOG: Myelin Oligodendrocyte Glycoprotein; MRI: Magnetic
Resonance Imaging; MS: Multiple Sclerosis; OspA: Outer Surface
Protein A; PLP: Proteo Lipid Protein; PPMS: Primary Progressive
Multiple Sclerosis; RRMS: Relapsing Remitting Multiple Sclerosis;
SPMS: Secondary Progressive Multiple Sclerosis; VCAM-1: Vascular
Cell Adhesion Molecule 1; VLA-4: Very Late Activation Antigen 4 $B$ cells in Central Nervous System Inflammation

After the differentiation from pro- and pre-B cell precursors in the bone marrow, naïve immature $\mathrm{B}$ cells migrate to secondary lymphoid tissues, predominantly the spleen, in order to emerge as $\mathrm{CD} 19+\mathrm{CD} 20+$ surfaceIgM-surfaceIgD+ mature naïve $\mathrm{B}$ cells [1]. Following an antigen-driven germinal center reaction in secondary lymphoid organs and stimulation by dendritic cells and $\mathrm{T}$ cells, $\mathrm{B}$ cells get activated and subsequently differentiate into $\mathrm{CD} 19+\mathrm{CD} 20+\mathrm{CD} 27+\mathrm{CD} 38+\mathrm{CD} 138-$ memory $\mathrm{B}$ cells and antibody-secreting effector cells, consisting of CD19+CD20CD27++CD38++CD138+HLA-DR++ plasma blasts and CD19CD20-CD27++CD38+CD138+HLA-DR- plasma cells [2]. Whereas plasma blasts are short-lived and disappear quickly after removal of their challenging antigen, plasma cells persist for several months to years in their specific survival niches, such as inflamed tissue or the bone marrow [3]. Different functions and phenotypes of various B-cell populations are shown in Figure 1.

$\mathrm{B}$ cells are largely absent in the cerebrospinal fluid (CSF) in noninflammatory conditions, but accumulate during central nervous system(CNS) inflammation [4]. In acute infectious diseases or chronic inflammatory disorders, B cells represent up to $30 \%$ of all cells in the CSF [5-8]. Oligoclonal bands and intrathecal immunoglobulin (Ig) synthesis are found in a variety of subacute and chronic infections of the CNS, like human $\mathrm{T}$ cell lymphotrophic virus-associated myelopathy, subacute sclerosing panencephalitis, human immunodeficiency virus (HIV) infection of the CNS, neurosyphilis, cryptococcal and mumps meningitis and neuroborreliosis [8-10]. In these diseases, the intrathecal Ig response is specific to the underlying infectious agent [11-15], whereas the target of the intrathecal antibody response in multiple sclerosis (MS) is still unknown.

Before we highlight the role of CSF B cells in neurological diseases, it is necessary to introduce the reader to the current understanding of immune cell trafficking into the brain. Cells of the immune system have access to the three distinct anatomical compartments (CSF, meninges and brain parenchyma), which are all relevant for CNS inflammation $[16,17]$. Whereas the migration of leukocytes into the brain parenchyma occurs at the blood-brain barrier (BBB), a highly specialized membrane, the migration of leukocytes into the CSF occurs through the choroid plexus into the subarachnoid space which contains the CSF, as illustrated in Figure 2. The choroid plexus is a specific anatomical structure located in brain ventricles. The CSF is secreted by modified epithelial cells of the choroid plexus, which are also known as Kolmer cells. In contrast to the BBB, the choroid plexus allows immune cells, particularly lymphocytes, an easier passage into the CSF [17].Thus, the CSF contains less innate immune cells and more lymphocytes than peripheral blood [18]. Trafficking of immune cells into the CSF is increased in CNS inflammation and according to the hallmark publication of Reiber and Peter in 2001, the total cell count in CSF represents the most sensitive parameter for characterization of an acute inflammatory disease of the CNS. Whereas in normal CSF 0-4 leukocytes/ $\mu \mathrm{l}$ are observed, CSF leukocyte counts are moderately increased in MS and significantly higher in acute infectious brain inflammation such as meningitis or meningoencephalitis [19]. In summary, inflammatory CNS disorders are characterized by the occurrence of intrathecal Ig synthesis and pleocytosis in the CSF.

*Corresponding author: Markus Reindl, PhD, Clinical Department of Neurology, Innsbruck Medical University, Anichstrasse 35, 6020 Innsbruck, Austria, E-mail: Markus.Reindl@i-med.ac.at

Received July 16, 2011; Accepted January 19, 2012; Published January 22 2012

Citation: Gredler V, Reindl M (2012) B Cells Accumulate in the Cerebrospinal Fluid in Inflammatory Neurological Diseases. J Cytol Histol S1:001. doi:10.4172/21577099.S1-001

Copyright: $\odot 2012$ Gredler V, et al. This is an open-access article distributed under the terms of the Creative Commons Attribution License, which permits unrestricted use, distribution, and reproduction in any medium, provided the original author and source are credited. 
Citation: Gredler V, Reindl M (2012) B Cells Accumulate in the Cerebrospinal Fluid in Inflammatory Neurological Diseases. J Cytol Histol S1:001. doi:10.4172/2157-7099.S1-001

Page 2 of 7

\section{Multiple Sclerosis}

MS is the most frequent, chronic inflammatory demyelinating disease of the CNS, mainly affecting young adults and characterized by a heterogeneous clinical presentation [20,21]. Although, the etiology of MS is still unknown, it is widely considered as autoimmune disease triggered by environmental factors in genetically susceptible individuals [22]. Worldwide, approximately 2.5 million peoplesuffer from MS. $85-90 \%$ of MS patients initially present with relapsing-remitting MS (RRMS) characterized by acute relapses followed by complete or incomplete remission [21]. The majority of these patients later convert to a secondary progressive disease course (SPMS). 10-15\% of patients suffer from primary progressive MS (PPMS), a malignant disease with steady progression from the onset. Current treatments for MS attempt
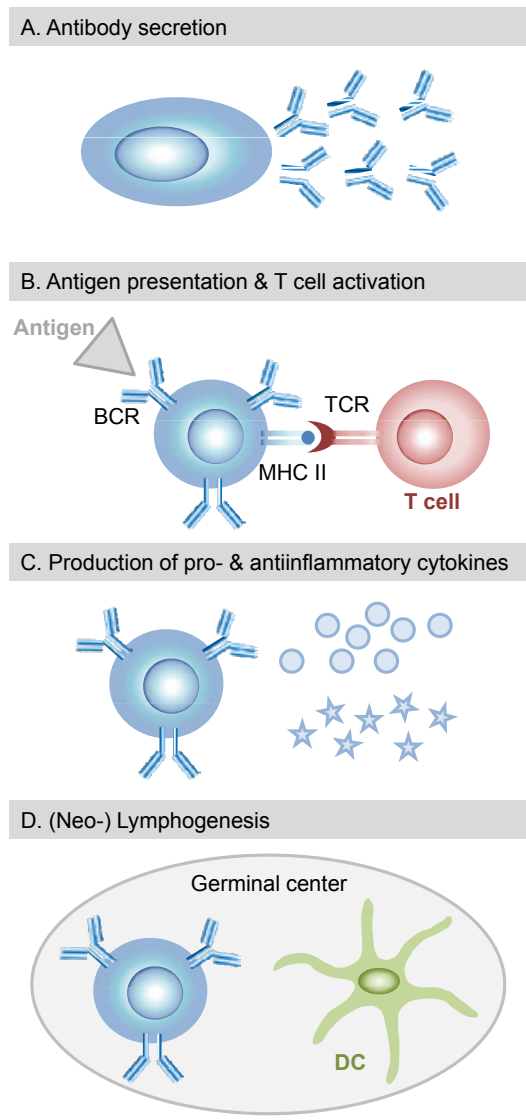

Figure 1: Phenotype and function of different B cell populations.

This illustration shows the four main functions of B cells in immune-mediated diseases of the CNS.

(A) CD19-CD20 low CD27++CD138+long-lived plasma cells and CD19 low CD27+CD138+ plasma blasts secrete antibodies that contribute to tissue damage via antibody-dependent cell-mediated cytotoxicity or complement activation.

(B) CD19+CD20+ activated B cells are potent APC that mediate cytokine secretion and clonal expansion of cytotoxic T cells.

(C) Production of pro- or anti-inflammatory cytokines by CD19+CD20+ B cells may affect the activation of macrophages or T cells.

(D) Plasma cells, plasma blasts and CD20+ B cells may be involved in de novo formation and maintenance of ectopic germinal centers in the intermeningeal spaces (neolymphogenesis).

Abbreviations: APC: Antigen-Presenting Cells; BCR: B Cell Receptor; DC: Dendritic Cell; MHC: Major Histocompatibility Complex; TCR: T Cell Receptor. Illustration modified from Barun and Bar-or [95]. to reduce the inflammatory activity by immunomodulation, prevent the entry of immune cells into the CNS, deplete specific subsets of immune cells or suppress immune responses in an unspecific manner [21]. The discovery of intermeningeal ectopic germinal centers, associated with $\mathrm{B}$ cells and high concentrations of germinal center promoting cytokines and chemokines like CxCL-13, suggest the de novo formation of ectopic lymphoid structures (neolymphogenesis) within the CNS [23-26]. These observations foster the crucial contribution of B cells in MS. Although, intensive and controversial research on the role of $\mathrm{B}$ cells in MS is ongoing for several years [27].

\section{Intrathecal Ig Synthesis in MS}

More than $90 \%$ of MS patients show a persistent increased intrathecal production of Ig, mainly consisting of oligoclonal IgG [28]. Oligoclonal IgG bands are restricted to the CSF [29] and their presence is an important marker for the diagnosis of MS [10]. Additionally, oligoclonal IgM synthesis in the CSF occurs in about $40 \%$ of MS patients [30]. Although many efforts have been made to identify the targets of the intrathecally produced antibodies, they are still largely unknown [31]. Recently, Owens et al. described that CSF IgG antibodies do not target myelin oligodendrocyte protein (MOG), myelin basic protein(MBP) and proteo lipid protein(PLP), three of the major myelin proteins, and do only weakly react with MS brain tissue [32]. In contrast, myelin lipids were identified as main targets for oligoclonal IgM bands in more than $70 \%$ of cases $[33,34]$ and a higher IgM index at clinical onset of MS correlates with faster progression of the disease, thereby predicting an aggressive MS disease course [33,3537]. Furthermore, a follow-up study showed that the more aggressive MS disease course in the presence of lipid-specific IgM bands is characterized by the occurrence of more relapses and higher disability [34]. Villar et al. [34] found an increased number of persisting IgM secreting CD19+CD5+ B cells in the CSF of MS patients with anti-lipid IgM oligoclonal bands compared to patients with IgM bands lacking myelin lipid specificity. By longitudinal analysis of CSF and serum samples from oligoclonal IgM band positive patients with and without lipid-specificity, it was shown that lipid-specific oligoclonal IgM bands persist for approximately two years, thus indicating a persistent immune response. In contrast, oligoclonal IgM bands without lipidspecificity at disease onset disappeared 18 months later, thus suggesting a transient immune response [34]. In summary, intrathecal synthesis of immunoglobulins, especially IgG is a useful marker for the diagnosis of MS, although the targets of these antibodies are not fully resolved yet. Moreover, B cells, plasma cells and excess immunoglobulins are found in MS lesions and B cell follicle-like structures in the meninges of MS patients have been discovered [23,38,39]. Recent data of successful clinical trials using rituximab, a monoclonal chimeric antibody targeting CD20, expressed on B cells, support the crucial role of B cells in MS pathology, thus indicating B cells as key players in MS disease activity [40].

\section{$B$ cells in the CSF of MS Patients}

Whereas there are no differences in the distribution of leukocyte subsets in the peripheral blood, impressing variations in leukocyte populations in the CSF of MS patients compared to non-inflammatory neurological diseases can be monitored [4]. CD19+ B cells, which are nearly absent in the CSF of healthy individuals and patients with non inflammatory neurological diseases, were shown to accumulate in the CSF during CNS inflammation [4,7]. In addition, a more progressive 
Citation: Gredler V, Reindl M (2012) B Cells Accumulate in the Cerebrospinal Fluid in Inflammatory Neurological Diseases. J Cytol Histol S1:001. doi:10.4172/2157-7099.S1-001

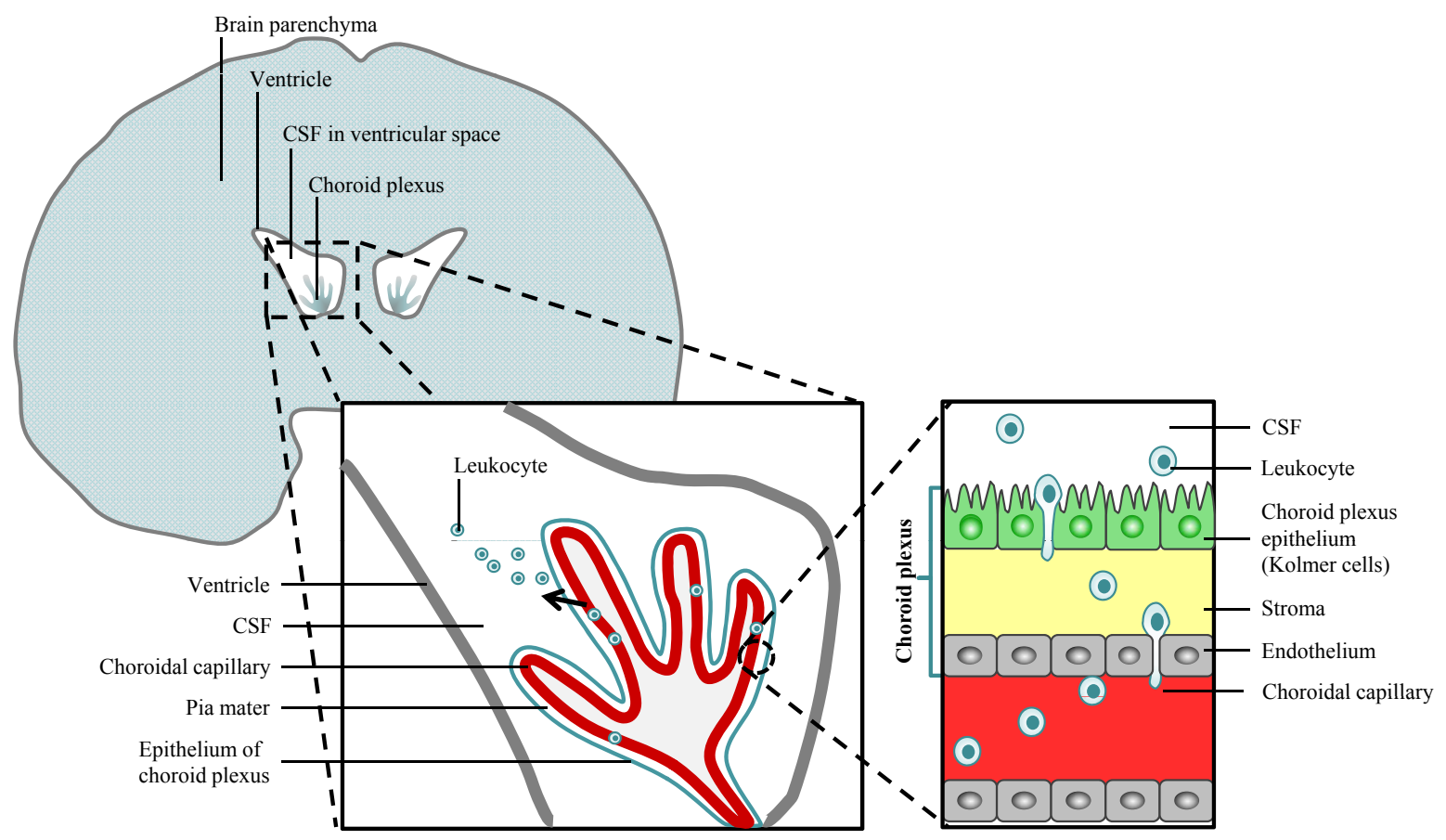

Figure 2: Transmigration of immune cells across the choroid plexus into the CSF.

Under the influence of chemokines immune cells in the small choroidal capillaries undergo adhesion, rolling and finally diapedesis into the stroma. There, the cells might be attracted by additional chemokines, produced by the CSF-secreting epithelial cells of the choroid plexus (Kolmer cells), thus resulting in migration through the epithelial cell layer into the ventricle.

Abbreviation: CSF: Cerebro Spinal Fluid.

Illustration modified from Wilson et al. [17] and Ransohoff et al. [16].

disease course of MS strongly correlates, next to intrathecal IgG production and oligoclonal IgM bands, with a preponderance of B cells $[4,37,41]$. As opposed to the peripheral blood, only a small quantity of CD19+CD27- naïve B cells is present in the CSF of MS patients [6].

In CNS inflammatory conditions, most B cells in the CSF are CD27 expressing antigen-experienced memory $\mathrm{B}$ cells and short-lived CD19+CD27++CD138+ plasma blasts $[6,7,24,42,43]$. Cepok and colleagues showed that almost $50 \%$ of B lymphocytes in the CSF are plasma blasts, a phenotype which is only infrequently found in the peripheral blood of MS patients [6], but which is abundant in the peripheral blood of patients with systemic lupus erythematosus [44,45]. Plasma blasts in the CSF were found to be discriminated from naïve as well as memory B cells by their increased size and density, representing a higher activation state [6]. Moreover, it was shown that the quantity of CD19+CD138+ plasma blasts in the CSF correlates with intrathecal IgG synthesis and inflammatory parenchymal disease activity, as monitored by the number and volume of gadolinium-enhancing lesions in T1-weighted magnetic resonance images (MRI) [6,7]. By analyzing CD19+CD27+ memory B cells in more detail, two distinct subsets depending on the strength of CD27 expression have been identified. One subset is characterized by a high expression (CD19+CD27++) while the other exhibits only an intermediate expression of $\mathrm{CD} 27$ $(\mathrm{CD} 19+\mathrm{CD} 27+)[6]$. By further analyzing the two distinct subsets of CD19+CD27+ memory B cells for the expression of CD138, high expression of CD138 was mainly found on CD19+CD27++ B cells. Furthermore, the $\mathrm{CD} 19+\mathrm{CD} 27++\mathrm{B}$ cell subset was shown to express lower levels of CD19 than naïve CD19+CD27- and memory CD19+CD27+ B cells [6]. In addition, CD19+CD27++ B cells express high levels of $\mathrm{CD} 38$, thereby representing a phenotype comparable with plasma blasts [6]. Recently, our group could demonstrate that the number of CSF B cells correlates with intrathecal production of matrix metalloproteinase-9 (MMP-9) and CxCL-13,two mediators promoting B cell migration through the $\mathrm{BBB}$ and maintenance of immune responses within the CNS [7]. MMP-9, which may be secreted by leukocytes and CNS-resident cells under inflammatory conditions, is involved in the degradation of the extracellular matrix, thereby promoting BBB leakage and subsequent transmigration of leukocytes into the brain $[7,46-$ 48]. CxCL-13 is a key regulator for B cells within lymphoid tissues and follicles, produced by stromal cells of germinal centers but also by monocytes, macrophages and dendritic cells [49-53]. It was shown several times that both mediators, MMP-9 and CxCL-13 are increased in the CSF of patients affected with MS as well as neuroborreliosis thereby explicating the accumulation of B cells in the CSF [50,54-60]. In addition, an obvious accumulation of CD19+CD138- mature B cells and CD19+CD138+ plasma blasts was observed in the CSF of patients affected with CIS and RRMS, but not in Chronic Progressive MS (CPMS), suggesting active inflammation [7]. The quantity of mature B cells and plasma blasts was associated with higher disease activity, as measured by the number of T2 lesions as well as the presence of gadolinium-enhancing lesions, referring to acute brain inflammation and BBB dysfunction [7]. Cepok and colleagues investigated the expression of CD19 and CD27 on CD138+ B cells in more detail [6]. They found that the majority of CD138+ B cells expresses high levels of CD27, HLA-DR as well as intermediate to high levels of CD19, a phenotype comparable to short-lived plasma blasts [6]. By longitudinally investigating the num- 
Citation: Gredler V, Reindl M (2012) B Cells Accumulate in the Cerebrospinal Fluid in Inflammatory Neurological Diseases. J Cytol Histol S1:001. doi:10.4172/2157-7099.S1-001

ber of CD19+CD138+ plasma blasts in the CSF of $61 \mathrm{MS}$ patients as well as 10 patients affected with other inflammatory neurological diseases, Cepok and colleagues showed that plasma blasts persist throughout the disease course of MS. However they disappear from the CSF of patients affected with infectious inflammatory CNS disorders like neuroborreliosis or viral meningitis after the clearance of the pathogen [6]. In contrast to plasma blasts in the CSF, CD19+CD138- mature B cells were shown to persist for years in various inflammatory CNS diseases (MS, neuroborreliosis and viral meningitis) [6]. Another study aimed to analyze the heterogeneous group of CD19+CD27+ memory B cells in the CSF of various inflammatory diseases like MS, CIS, viral meningitis or meningoencephalitis in more detail and found a selective enrichment of class-switched IgM-IgD-CD27+ memory B cells [42]. In contrast, the transmigration of $\mathrm{CD} 19+\mathrm{CD} 27-$ naive $\mathrm{B}$ cells from the periphery into the CNS was found to be largely prohibited [42]. Since the majority of patients suffer from RRMS, analysis of the immune cell subpopulations in the CSF during remission and clinical relapses were performed. Investigations in five RRMS patients revealed variations in the absolute white cell count whereas the distribution of different immune cell subpopulations (monocytes and B cells) remained stable [4]. The authors speculate that the patterns of CSF cytology in MS patients do not correspond to the various disease phases; however they suggest that the variations may reflect individual differences in immune reactivity with a predominance of B cells in some patients and monocytes in others. Furthermore, higher numbers of B cells relative to monocytes correlate with faster disease progression [4]. In addition, in a subgroup of patients suffering from RRMS and SPMS they found that high numbers of B cells and low numbers of monocytes are associated with a higher progression rate [4]. There are inconsistent reports on the frequency of plasma cells in the CSF of MS patients. While some data suggests increased numbers of CD19-CD138+ long-living plasma cells in the CSF from MS patients [24], others report only low counts of plasma cells with unchanged frequencies, regardless of the disease duration and the MS disease course [6,7]. Moreover, Corcione et al. [24] reported CD19+CD38+CD77+centroblasts in the CSF of MS patients. In addition to analysis of the CSF B cell composition in untreated MS patients, several approaches aimed to evaluate the effect of various MS treatments on CSF B cells. Thereby, the effects of natalizumab on CSFB cells have been investigated. Natalizumab is a humanized monoclonal antibody, specific for very late activation antigen 4 (VLA-4), an adhesion molecule which is expressed by all white blood cells except neutrophils. Binding of natalizumabto VLA-4 inhibits the interaction of VLA-4 with its ligand vascular cell adhesion molecule 1 (VCAM-1), thus preventing leukocyte transmigration into the CNS [61]. By analyzing the number of white blood cells in the CSF, it was shown that natalizumab results in a decline in all major leukocyte subsets [61]. This effect was sustained even six months after termination of therapy, where among others, the numbers of CD19+B cells and CD138+ plasma cells remained lower in treated MS patients, compared to untreated MS patients [61]. However, the quantity of lymphocytes reverted to normal 14 months after cessation of natalizumab treatment [62]. Since beneficial effects of therapies targeting CD20 in MS have been reported, the effects of $B$ cell depletion using rituximab were investigated in the peripheral blood and in the CSF $[40,63]$. Rituximab was found to decrease the quantity of $B$ cells in the peripheral blood as well as in the CSF [64-67]. By analyzing B cells for the expression of co-stimulatory molecules pre- and post rituximab, Piccio et al. found that the total number of B cells in the CSF significantly decreased post-treatment. However, the proportion of B lymphocytes expressing co-stimulatory molecules CD80 and CD86 was significantly increased post-treatment [64]. Moreover, it was shown that rituximab effectively depletes B cells in the cerebral perivascular spaces, the main CNS compartment in which antigen presentation and T cell reactivation occurs [67]. Fingolimod (FTY720), an oral immunomodulatory drug, was recently approved for the treatment of RRMS [68-70]. One study showed that although fingolimod significantly decreases B cells in the periphery, it only had little impact on CSF B cells [71]. In conclusion, the accumulation of B cells, particularly of CD19+CD27++CD138+plasma blasts, in the CSF establishes them as one of the central players in active MS. Furthermore, their numbers were found to correlates with intrathecal immunoglobulin synthesis, intrathecal production of CxCL-13 and MMP-9 as well as acute brain inflammation. Moreover, recent promising results of novel therapeutic approaches, either targeting the entry of leukocytes into the brain or depleting B cells, underpin their importance in chronic inflammatory demyelinating diseases, like MS.

\section{B cells in Neuroborreliosis}

Lyme borreliosis is a multisystem disease caused by infections with the spirochete Borrelia (B.)burgdorferisensulato transmitted by ticks of the species Ixodes [72-75]. The prevalence of Lyme borreliosis ranges from $20-100$ per 100,000 in the US to $100-130$ per 100,000 in Europe [76,77]. So far, four human pathogenic species of B.burgdorferisensulato have been described [77]. In Europe the genospecies B.burgdorferisensustricto, B.garinii, B.afzelii and B.spielmanii exist. By contrast, in the US only one human pathogenic species, B.burgdorferisensustricto is present [72,77-81]. Whereas all genospecies may cause erythema migrans, B.afzelii has been mainly associated with Acrodermatitis Chronic Atrophicans, B.burgdorferisensostricto with arthritis and B.garinii is predominantly associated with neurological manifestations of the disease [78]. Lyme neuroborreliosis is a severe inflammatory manifestation affecting the peripheral and central nervous system $[77,82]$. It may lead to multiple pathological and clinical symptoms like lymphocytic meningitis, meningoencephalitis, cranial or peripheral neuritis and painful meningoradiculitis $[74,77,83,84]$. Acute painful meningoradiculitis is the most frequent CNS manifestation observed in Europe [5]. In meningoradiculitis it is assumed that the spirochete B.burgdorferi infects the brain and the meninges, although the patho mechanism is not fully understood so far [5]. In the majority of cases, the immune response in the CNS successfully clears the infection, resulting in remission of the symptoms [5]. Nevertheless, chronic neurologic diseases, like encephalomyelitis can occur in about $10-20 \%$ of untreated patients infected with B.burgdorferi, even after long periods of latent infection, thereby aggravating correct diagnosis $[5,76,84]$. Neuroborreliosis leads to local inflammation in the host and accumulation of leukocytes in the CSF $[5,85]$. MRI studies in late, chronic disease stages showed diffuse white matter lesions [86]. In addition to CSF-derived T cells, reactive with either B.burgdorferi-derived antigens or CNS-self antigens [87], T cells cross-reactive with both were detected $[88,89]$. Thus indicating that autoimmunity triggering the chronic disease is provoked by molecular mimicry $[88,89]$. The presence of antigen-triggered immunity is fostered by the presence of oligoclonal IgG and IgM bands in the CSF of affected individuals [5]. The presence of intrathecal B.burgdorferi-specific antibody production is partly considered to be essential for the diagnosis of neuroborreliosis [84]. The intrathecal synthesis of immunoglobulins may persist for several months or years after treatment [84]. Some approaches have analyzed the targets of immunoglobulinsin the CSF of patients affected with neuroborreliosis. 
Citation: Gredler V, Reindl M (2012) B Cells Accumulate in the Cerebrospinal Fluid in Inflammatory Neurological Diseases. J Cytol Histol S1:001. doi:10.4172/2157-7099.S1-001

These studies detected IgG specific for B. burgdorferi [90,91] but also CNS autoantigens [92]. Another study analyzed independently clonally expanded CD138+ plasma cells from the CSF and found distinct reactivities, for $B$. burgdorferi-derived antigens and CNS autoantigens, thus indicating that mechanisms involving molecular mimicry are absent in neuroborreliosis [83]. Cepok and colleagues reported high percentages of B cells and plasma cells in the CSF of patients affected with $B$. burgdorferi meningoradiculitis at disease onset, compared to non-inflammatory neurological diseases and viral meningitis [5]. During the first weeks of recovery, $\mathrm{CD} 19+\mathrm{B}$ cells were found to persist or even relatively increase in the CSF, and high $\mathrm{B}$ cell counts were found even after more than 100 days in the CSF [5]. In contrast to B cells, the number of CD19-CD138+ plasma cells in the CSF was found to decrease immediately to less than $0.5 \%$ one monthafter initiation of antibiotic treatment. Furthermore, lower numbers of natural killer $\mathrm{T}$ cells and monocytes were detected in the CSF of patients affected with neuroborrelios is compared to non-inflammatory disorders [5]. In addition, it was shown that the percentage of plasma cells correlates with the absolute levels of intrathecally synthesized IgG and IgM, whereas it does not correlate with $B$. burgdorferi-specific IgG antibody production. However, B. burgdorferi-specific IgG antibody synthesis was found to correlate with the percentage of CSF B cells [5]. In contrast to variations in the cellular distribution in the CSF, no differences of immune cell subsets in the peripheral blood of patients affected with neuroborrelios is compared to non-inflammatory controls have been detected [5]. Furthermore, it was shown that the lipid moiety of Borreliaouter surface protein A (OspA) provokes polyclonal B cell activation [93], which can subsequently lead to $B$ cell maturation into plasma cells associated with the secretion of B. burgdorferi-specific antibodies [72]. The large numbers of infiltrating B cells in the CSF $[5,6]$ are probably attracted by the relatively high intrathecal levels of CxCL-13, observed in neuroborreliosis $[54,77,94]$. Within the CSF, attracted B cells may mature into antibody-secreting plasma cells, thus producing $B$. burgdorferi-specific antibodies [72]. By longitudinally analyzing paired CSF and serum samples from one patient with definite neuroborreliosis, Tumani et al. [82] found a mononuclear cell pleocytosis, activated $\mathrm{B}$ cells and intrathecal humoral immune response with IgM predominance as well as blood-CSF barrier dysfunction which persisted for several weeks. Like in MS, differences in the distribution of various B cell subsets in neuroborreliosis are exclusively observed in the CSF, thus underpinning the role of CSF B cells in neuroinflammation. Moreover, in the CSF of patients affected with neuroborreliosis, intrathecally synthesized IgG as well as IgM, reactive against $B$. burgdorferi-specific antigens as well as CNS autoantigens were detected, thus fostering the impact of humoral immunity.

Apart from bacterial infections, B cells are also involved in various viral infections of the CNS. B cell and plasma blast counts in the CSF were shown to be increased in patients infected with human immunodeficiency virus (HIV), compared to patients with noninfectious CNS disorders. It was shown that the quantity of B cells during early and late stages of HIV infections remain stable. This is in contrast to plasma blasts which were found in higher numbers during early stages of HIV infection. Moreover in HIV, the prevalence of CSF plasma blasts was shown to correlate with intrathecal IgG synthesis as well as with HIV RNA copy numbers in the CSF. In addition, initiation of antiviral treatment in HIV patients resulted in a decrease in the number of plasma blasts as well as reduced HIV RNA copy numbers within the CSF. The results indicate a HIV-triggered B cell response and furthermore, plasma blasts as the main virus-related B lymphocyte subset [8].

\section{Conclusion and Outlook}

Although MS is widely considered as T cell-mediated autoimmune disease of the CNS, there is accumulating evidence that B cells are key components in the pathogenesis of the disease. B cells may contribute at multiple sites to MS pathogenesis. As shown in Figure 1, B cells participate, next to their obvious role in antibody-secretion, in antigen-presentation as well as cytokine and chemokine production. Furthermore, the successful application of monoclonal antibodies targeting CD20 in MS patients confirmed, as stated by Barun and BarOr, "that it is no longer a question of whether B cells contribute, but how they contribute, to MS disease activity" [95].

Besides numerous other infectious diseases, B cells play an important role in Lyme neuroborreliosis. Via the secretion of B.burgdorferi-specific antibodies, B cells in the CNS contribute to the clearance of the underlying bacterial infection.

Although, several mechanisms of B cell-mediated immunity are well understood so far, their complex functions are not clarified in detail and require further studies.

\section{References}

1. Shapiro-Shelef M, Calame K (2005) Regulation of plasma-cell development Nat Rev Immunol 5: 230-242.

2. MacLennan IC (1994) Germinal centers. Annu Rev Immunol 12: 117-139.

3. Bernasconi NL, Traggiai E, Lanzavecchia A (2002) Maintenance of serological memory by polyclonal activation of human memory B cells. Science 298: 21992202.

4. Cepok S, Jacobsen M, Schock S, Omer B, Jaekel S, et al. (2001) Patterns of cerebrospinal fluid pathology correlate with disease progression in multiple sclerosis. Brain 124: 2169-2176.

5. Cepok S, Zhou D, Vogel F, Rosche B, Grummel V, et al. (2003) The immune response at onset and during recovery from Borrelia burgdorferi meningoradiculitis. Arch Neurol 60: 849-855

6. Cepok S, Rosche B, Grummel V, Vogel F, Zhou D, et al. (2005) Short-lived plasma blasts are the main $B$ cell effector subset during the course of multiple sclerosis. Brain 128: 1667-1676.

7. Kuenz B, Lutterotti A, Ehling R, Gneiss C, Haemmerle M, et al. (2008) Cerebrospinal fluid $B$ cells correlate with early brain inflammation in multiple sclerosis. PLoS One 3: e2559.

8. Cepok S, von Geldern G, Nolting T, Grummel V, Srivastava R, et al. (2007) Viral load determines the B-cell response in the cerebrospinal fluid during human immunodeficiency virus infection. Ann Neurol 62: 458-467.

9. Ritchie AM, Gilden DH, Williamson RA, Burgoon MP, Yu X, et al. (2004) Comparative analysis of the CD19+ and CD138+ cell antibody repertoires in the cerebrospinal fluid of patients with multiple sclerosis. J Immunol 173: 649656 .

10. Freedman MS, Thompson EJ, Deisenhammer F, Giovannoni G, Grimsley G, et al. (2005) Recommended standard of cerebrospinal fluid analysis in the diagnosis of multiple sclerosis: a consensus statement. Arch Neurol 62: 865870 .

11. Vandvik B, Norrby E, Nordal HJ, Degre M (1976) Oligoclonal measles virusspecific IgG antibodies isolated from cerebrospinal fluids, brain extracts, and sera from patients with subacute sclerosing panencephalitis and multiple sclerosis. Scand J Immunol 5: 979-992.

12. Vartdal F, Vandvik B, Michaelsen TE, Loe K, Norrby E (1982) Neurosyphilis: intrathecal synthesis of oligoclonal antibodies to Treponema pallidum. Ann Neurol 11: 35-40.

13. Wilske B, Schierz G, Preac-Mursic V, von Busch K, Kuhbeck R, et al. (1986) Intrathecal production of specific antibodies against Borrelia burgdorferi in 
Citation: Gredler V, Reindl M (2012) B Cells Accumulate in the Cerebrospinal Fluid in Inflammatory Neurological Diseases. J Cytol Histol S1:001. doi:10.4172/2157-7099.S1-001

Page 6 of 7

patients with lymphocytic meningoradiculitis (Bannwarth's syndrome). J Infect Dis 153: 304-314.

14. Grimaldi LM, Roos RP, Devare SG, Casey JM, Maruo Y, et al. (1988) HTLVI-associated myelopathy: oligoclonal immunoglobulin $G$ bands contain antiHTLV-I p24 antibody. Ann Neurol 24: 727-731.

15. Kaiser R, Dorries R, Luer W, Poser S, Pohle HD, et al. (1989) Analysis of oligoclonal antibody bands against individual HIV structural proteins in the CSF of patients infected with HIV. J Neurol 236: 157-160.

16. Ransohoff RM, Kivisakk P, Kidd G (2003) Three or more routes for leukocyte migration into the central nervous system. Nat Rev Immunol 3: 569-581.

17. Wilson EH, Weninger W, Hunter CA (2010) Trafficking of immune cells in the central nervous system. J Clin Invest 120: 1368-1379.

18. Kivisakk P, Mahad DJ, Callahan MK, Trebst C, Tucky B, et al. (2003) Human cerebrospinal fluid central memory CD4+ T cells: evidence for trafficking through choroid plexus and meninges via P-selectin. Proc Natl Acad Sci U S A 100: 8389-8394.

19. Reiber H, Peter JB (2001) Cerebrospinal fluid analysis: disease-related data patterns and evaluation programs. J Neurol Sci 184: 101-122.

20. Noseworthy JH, Lucchinetti C, Rodriguez M, Weinshenker BG (2000) Multiple sclerosis. N Engl J Med 343: 938-952.

21. Compston A, Coles A (2008) Multiple sclerosis. Lancet 372: 1502-1517.

22. Sospedra M, Martin R (2005) Immunology of multiple sclerosis. Annu Rev Immunol 23: 683-747.

23. Serafini B, Rosicarelli B, Magliozzi R, Stigliano E, Aloisi F (2004) Detection of ectopic B-cell follicles with germinal centers in the meninges of patients with secondary progressive multiple sclerosis. Brain Pathol 14: 164-174.

24. Corcione A, Casazza S, Ferretti E, Giunti D, Zappia E, et al. (2004) Recapitulation of $B$ cell differentiation in the central nervous system of patients with multiple sclerosis. Proc Natl Acad Sci U S A 101: 11064-11069.

25. Harp C, Lee J, Lambracht-Washington D, Cameron E, Olsen G, et al. (2007) Cerebrospinal fluid $B$ cells from multiple sclerosis patients are subject to normal germinal center selection. J Neuroimmunol 183: 189-199.

26. Dalakas MC (2008) B cells as therapeutic targets in autoimmune neurological disorders. Nat Clin Pract Neurol 4: 557-567.

27. Cross AH, Waubant E (2011) MS and the B cell controversy. Biochim Biophys Acta 1812: 231-238.

28. Kabat EA, Glusman M, Knaub V (1948) Quantitative estimation of the albumin and gamma globulin in normal and pathologic cerebrospinal fluid by immunochemical methods. Am J Med 4: 653-662.

29. Kabat EA, Moore DH, Landow H (1942) An Electrophoretic Study of the Protein Components in Cerebrospinal Fluid and Their Relationship to the Serum Proteins. J Clin Invest 21: 571-577.

30. Villar LM, Masjuan J, Gonzalez-Porque P, Plaza J, Sadaba MC, et al. (2002) Intrathecal IgM synthesis in neurologic diseases: relationship with disability in MS. Neurology 58: 824-826.

31. Reindl M, Khalil M, Berger T (2006) Antibodies as biological markers for pathophysiological processes in MS. J Neuroimmunol 180: 50-62.

32. Owens GP, Bennett JL, Lassmann H, O'Connor KC, Ritchie AM, et al. (2009) Antibodies produced by clonally expanded plasma cells in multiple sclerosis cerebrospinal fluid. Ann Neurol 65: 639-649.

33. Villar LM, Sadaba MC, Roldan E, Masjuan J, Gonzalez-Porque P, et al. (2005) Intrathecal synthesis of oligoclonal IgM against myelin lipids predicts an aggressive disease course in MS. J Clin Invest 115: 187-194.

34. Villar L, Garcia-Barragan N, Espino M, Roldan E, Sadaba M, et al. (2008) Influence of oligoclonal IgM specificity in multiple sclerosis disease course. Mult Scler 14: 183-187.

35. Perini P, Ranzato F, Calabrese M, Battistin L, Gallo P (2006) Intrathecal IgM production at clinical onset correlates with a more severe disease course in multiple sclerosis. J Neurol Neurosurg Psychiatry 77: 953-955.

36. Villar LM, Masjuan J, Gonzalez-Porque P, Plaza J, Sadaba MC, et al. (2002) Intrathecal IgM synthesis predicts the onset of new relapses and a worse disease course in MS. Neurology 59: 555-559.
37. Villar LM, Masjuan J, Gonzalez-Porque P, Plaza J, Sadaba MC, et al. (2003) Intrathecal IgM synthesis is a prognostic factor in multiple sclerosis. Ann Neuro 53: 222-226.

38. Aloisi F, Pujol-Borrell R (2006) Lymphoid neogenesis in chronic inflammatory diseases. Nat Rev Immunol 6: 205-217.

39. Magliozzi R, Howell O, Vora A, Serafini B, Nicholas R, et al. (2007) Meningea $B$-cell follicles in secondary progressive multiple sclerosis associate with early onset of disease and severe cortical pathology. Brain 130: 1089-1104.

40. Hauser SL, Waubant E, Arnold DL, Vollmer T, Antel J, et al. (2008) B-cell depletion with rituximab in relapsing-remitting multiple sclerosis. $\mathrm{N}$ Engl J Med 358: 676-688.

41. Izquierdo G, Angulo S, Garcia-Moreno JM, Gamero MA, Navarro G, et al. (2002) Intrathecal IgG synthesis: marker of progression in multiple sclerosis patients. Acta Neurol Scand 105: 158-163.

42. Cepok S, von Geldern G, Grummel V, Hochgesand S, Celik H, et al. (2006) Accumulation of class switched IgD-lgM- memory B cells in the cerebrospinal fluid during neuroinflammation. J Neuroimmunol 180: 33-39.

43. Winges KM, Gilden DH, Bennett JL, Yu X, Ritchie AM, et al. (2007) Analysis of multiple sclerosis cerebrospinal fluid reveals a continuum of clonally related antibody-secreting cells that are predominantly plasma blasts. J Neuroimmunol 192: 226-234.

44. Jacobi AM, Odendahl M, Reiter K, Bruns A, Burmester GR, et al. (2003) Correlation between circulating CD27high plasma cells and disease activity in patients with systemic lupus erythematosus. Arthritis Rheum 48: 1332-1342.

45. Odendahl M, Jacobi A, Hansen A, Feist E, Hiepe F, et al. (2000) Disturbed peripheral B lymphocyte homeostasis in systemic lupus erythematosus. J Immunol 165: 5970-5979.

46. Sellebjerg F, Sorensen TL (2003) Chemokines and matrix metalloproteinase-9 in leukocyte recruitment to the central nervous system. Brain Res Bull 61: 347 355

47. Yong VW, Krekoski CA, Forsyth PA, Bell R, Edwards DR (1998) Matrix metalloproteinases and diseases of the CNS. Trends Neurosci 21: 75-80.

48. Leppert D, Waubant E, Galardy R, Bunnett NW, Hauser SL (1995) T cel gelatinases mediate basement membrane transmigration in vitro. $\mathrm{J}$ Immuno 154: $4379-4389$

49. Carlsen HS, Baekkevold ES, Morton HC, Haraldsen G, Brandtzaeg P (2004) Monocyte-like and mature macrophages produce CXCL13 (B cell-attracting chemokine 1) in inflammatory lesions with lymphoid neogenesis. Blood 104 3021-3027.

50. Krumbholz M, Theil D, Cepok S, Hemmer B, Kivisakk P, et al. (2006) Chemokines in multiple sclerosis: CXCL12 and CXCL13 up-regulation is differentially linked to CNS immune cell recruitment. Brain 129: 200-211.

51. Meinl E, Krumbholz M, Hohlfeld R (2006) B lineage cells in the inflammatory central nervous system environment: migration, maintenance, local antibody production, and therapeutic modulation. Ann Neurol 59: 880-892.

52. Narayan K, Dail D, Li L, Cadavid D, Amrute S, et al. (2005) The nervous system as ectopic germinal center: CXCL13 and IgG in lyme neuroborreliosis. Ann Neurol 57: 813-823.

53. Rupprecht TA, Kirschning CJ, Popp B, Kastenbauer S, Fingerle V, et al. (2007) Borrelia garinii induces CXCL13 production in human monocytes through Tolllike receptor 2. Infect Immun 75: 4351-4356.

54. Rupprecht TA, Pfister HW, Angele B, Kastenbauer S, Wilske B, et al. (2005) The chemokine CXCL13 (BLC): a putative diagnostic marker for neuroborreliosis. Neurology 65: 448-450.

55. Sellebjerg F, Bornsen L, Khademi M, Krakauer M, Olsson T, et al. (2009) Increased cerebrospinal fluid concentrations of the chemokine CXCL13 in active MS. Neurology 73: 2003-2010.

56. Festa ED, Hankiewicz K, Kim S, Skurnick J, Wolansky LJ, et al. (2009) Serum levels of CXCL13 are elevated in active multiple sclerosis. Mult Scler 15: 1271 1279.

57. Leppert D, Ford J, Stabler G, Grygar C, Lienert C, et al. (1998) Matrix metalloproteinase-9 (gelatinase B) is selectively elevated in CSF during relapses and stable phases of multiple sclerosis. Brain 121: 2327-2334.

58. Mandler RN, Dencoff JD, Midani F, Ford CC, Ahmed W, et al. (2001) Matrix 
Citation: Gredler V, Reindl M (2012) B Cells Accumulate in the Cerebrospinal Fluid in Inflammatory Neurological Diseases. J Cytol Histol S1:001. doi:10.4172/2157-7099.S1-001

metalloproteinases and tissue inhibitors of metalloproteinases in cerebrospinal fluid differ in multiple sclerosis and Devic's neuromyelitis optica. Brain 124: 493-498

59. Perides G, Charness ME, Tanner LM, Peter O, Satz N, et al. (1998) Matrix metalloproteinases in the cerebrospinal fluid of patients with Lyme neuroborreliosis. J Infect Dis 177: 401-408.

60. Kirchner A, Koedel U, Fingerle V, Paul R, Wilske B, et al. (2000) Upregulation of matrix metalloproteinase-9 in the cerebrospinal fluid of patients with acute Lyme neuroborreliosis. J Neurol Neurosurg Psychiatry 68: 368-371.

61. Stuve O, Marra CM, Jerome KR, Cook L, Cravens PD, et al. (2006) Immune surveillance in multiple sclerosis patients treated with natalizumab. Ann Neuro 59: 743-747.

62. Stuve O, Cravens PD, Frohman EM, Phillips JT, Remington GM, et al. (2009) Immunologic, clinical, and radiologic status 14 months after cessation of natalizumab therapy. Neurology 72: 396-401.

63. Bar-Or A, Calabresi PA, Arnold D, Markowitz C, Shafer S, et al. (2008) Rituximab in relapsing-remitting multiple sclerosis: a 72-week, open-label, phase I trial. Ann Neurol 63: 395-400.

64. Piccio L, Naismith RT, Trinkaus K, Klein RS, Parks BJ, et al. (2010) Changes in $\mathrm{B}$ - and T-lymphocyte and chemokine levels with rituximab treatment in multiple sclerosis. Arch Neurol 67: 707-714.

65. Cross AH, Stark JL, Lauber J, Ramsbottom MJ, Lyons JA (2006) Rituximab reduces $B$ cells and $T$ cells in cerebrospinal fluid of multiple sclerosis patients. J Neuroimmunol 180: 63-70.

66. Stuve O, Cepok S, Elias B, Saleh A, Hartung HP, et al. (2005) Clinical stabilization and effective B-lymphocyte depletion in the cerebrospinal fluid and peripheral blood of a patient with fulminant relapsing-remitting multiple sclerosis. Arch Neurol 62: 1620-1623.

67. Martin Mdel P, Cravens PD, Winger R, Kieseier BC, Cepok S, et al. (2009) Depletion of $B$ lymphocytes from cerebral perivascular spaces by rituximab. Arch Neurol 66: 1016-1020.

68. Cohen JA, Barkhof F, Comi G, Hartung HP, Khatri BO, et al. (2010) Oral fingolimod or intramuscular interferon for relapsing multiple sclerosis. $\mathrm{N}$ Engl J Med 362: 402-415.

69. Kappos L, Radue EW, O'Connor P, Polman C, Hohlfeld R, et al. (2010) A placebo-controlled trial of oral fingolimod in relapsing multiple sclerosis. $\mathrm{N}$ Engl J Med 362: 387-401.

70. Doggrell SA (2010) Oral fingolimod for relapsing-remitting multiple sclerosis Evaluation of: Kappos L, Radue E-M, O'Connor P, et al. A placebocontrolled trial of oral fingolimod in relapsing multiple sclerosis. $\mathrm{N}$ Engl $\mathrm{J}$ Med 2010;362:387-401; and Cohen JA, Barkhof F, Comi G, et al. Oral fingolimod or intramuscular interferon for relapsing multiple sclerosis. $\mathrm{N}$ Engl $\mathrm{J}$ Med 2010;362:402-15. Expert Opin Pharmacother 11: 1777-1781.

71. Kowarik MC, Pellkofer HL, Cepok S, Korn T, Kumpfel T, et al. (2011) Differential effects of fingolimod (FTY720) on immune cells in the CSF and blood of patients with MS. Neurology 76: 1214-1221.

72. Wilske B, Fingerle V, Schulte-Spechtel U (2007) Microbiological and serological diagnosis of Lyme borreliosis. FEMS Immunol Med Microbiol 49: 13-21.

73. Steere AC (1989) Lyme disease. N Engl J Med 321: 586-596

74. Pfister HW, Wilske B, Weber K (1994) Lyme borreliosis: basic science and clinical aspects. Lancet 343: 1013-1016.

75. Stanek G, Strle F (2003) Lyme borreliosis. Lancet 362: 1639-1647.

76. Hengge UR, Tannapfel A, Tyring SK, Erbel R, Arendt G, et al. (2003) Lyme borreliosis. Lancet Infect Dis 3: 489-500.
77. Rupprecht TA, Koedel U, Fingerle V, Pfister HW (2008) The pathogenesis of lyme neuroborreliosis: from infection to inflammation. Mol Med 14: 205-212.

78. Huppertz HI, Bohme M, Standaert SM, Karch H, Plotkin SA (1999) Incidence of Lyme borreliosis in the Wurzburg region of Germany. Eur J Clin Microbio Infect Dis 18: 697-703.

79. Wang G, van Dam AP, Dankert J (1999) Phenotypic and genetic characterization of a novel Borrelia burgdorferi sensu lato isolate from a patient with lyme borreliosis. J Clin Microbiol 37: 3025-3028.

80. Richter D, Postic D, Sertour N, Livey I, Matuschka FR, et al. (2006) Delineation of Borrelia burgdorferi sensu lato species by multilocus sequence analysis and confirmation of the delineation of Borrelia spielmanii sp. nov. Int J Syst Evol Microbiol 56: 873-881.

81. Richter D, Schlee DB, Allgower R, Matuschka FR (2004) Relationships of a novel Lyme disease spirochete, Borrelia spielmani sp. nov., with its hosts in Central Europe. Appl Environ Microbiol 70: 6414-6419.

82. Tumani H, Nolker G, Reiber H (1995) Relevance of cerebrospinal fluid variables for early diagnosis of neuroborreliosis. Neurology 45: 1663-1670.

83. Kuenzle S, von Budingen HC, Meier M, Harrer MD, Urich E, et al. (2007) Pathogen specificity and autoimmunity are distinct features of antigen-driven immune responses in neuroborreliosis. Infect Immun 75: 3842-3847.

84. Marques AR (2010) Lyme disease: a review. Curr Allergy Asthma Rep 10: 13 20.

85. Sindern E, Malin JP (1995) Phenotypic analysis of cerebrospinal fluid cells over the course of Lyme meningoradiculitis. Acta Cytol 39: 73-75.

86. Iero I, Elia M, Cosentino FI, Lanuzza B, Spada RS, et al. (2004) Isolated monolateral neurosensory hearing loss as a rare sign of neuroborreliosis. Neurol Sci 25: 30-33.

87. Martin R, Ortlauf J, Sticht-Groh V, Bogdahn U, Goldmann SF, et al. (1988) Borrelia burgdorferi--specific and autoreactive T-cell lines from cerebrospinal fluid in Lyme radiculomyelitis. Ann Neurol 24: 509-516.

88. Hemmer B, Gran B, Zhao Y, Marques A, Pascal J, et al. (1999) Identification of candidate T-cell epitopes and molecular mimics in chronic Lyme disease. Nat Med 5: 1375-1382.

89. Lunemann JD, Gelderblom H, Sospedra M, Quandt JA, Pinilla C, et al. (2007) Cerebrospinal fluid-infiltrating CD4+ $T$ cells recognize Borrelia burgdorfer lysine-enriched protein domains and central nervous system autoantigens in early lyme encephalitis. Infect Immun 75: 243-251.

90. Hansen K, Cruz M, Link H (1990) Oligoclonal Borrelia burgdorferi-specific IgG antibodies in cerebrospinal fluid in Lyme neuroborreliosis. J Infect Dis 161 1194-1202.

91. Martin R, Martens U, Sticht-Groh V, Dorries R, Kruger H (1988) Persisten intrathecal secretion of oligoclonal, Borrelia burgdorferi-specific lgG in chronic meningoradiculomyelitis. J Neurol 235: 229-233.

92. Kaiser R (1995) Intrathecal immune response in patients with neuroborreliosis: specificity of antibodies for neuronal proteins. J Neurol 242: 319-325.

93. Weis JJ, Ma Y, Erdile LF (1994) Biological activities of native and recombinant Borrelia burgdorferi outer surface protein $\mathrm{A}$ : dependence on lipid modification. Infect Immun 62: 4632-4636.

94. Schmidt C, Plate A, Angele B, Pfister HW, Wick M, et al. (2011) A prospective study on the role of CXCL13 in Lyme neuroborreliosis. Neurology 76: 1051 1058

95. Barun B, Bar-Or A (2011) Treatment of multiple sclerosis with Anti-CD20 antibodies. Clin Immunol. 